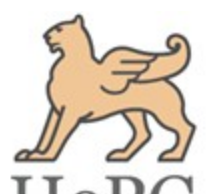

\title{
An insight into drought stress and signal transduction of abscisic acid
}

\author{
Arpna Kumari, Rajanbir Kaur and Rajinder Kaur* \\ Department of Botanical and Environmental Sciences, Guru Nanak Dev University, Amritsar-143005, Punjab, India
}

Article history

Received: 06 March 2018

Accepted: 05 April 2018

Published: 24 April 2018

(C) Kumari et al (2018)

Editor

K K Sabu

Publisher

Horizon e-Publishing Group

Correspondence

Rajinder Kaur

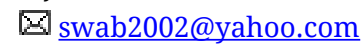

\begin{abstract}
The sustainable crop production is one of the major issue in the era of urbanization, industrialization, and globalization. In the environment, there are number of abiotic and biotic factors which are hampering the sustainable production of crops. The drought is one of the constraints which directly/indirectly affects the crop yield. It has various negative effects on the normal physiology and biochemistry of the plants. Therefore, researchers must have to work in the field of developing drought-tolerant crop plants to meet the food needs of the exponentially growing population of the world. The present study is the outcome of an extensive literature survey on the basic perturbations of drought to the crops, role of abscisic acid (ABA) in stressful conditions and its signal transduction.
\end{abstract}

\section{Keywords}

Drought stress; physiological consequences; ABA-dependent signaling; ABA-independent signaling; drought tolerance.

\section{Citation}

Kumari A, Kaur R, Kaur, R. An insight into drought stress and signal transduction of abscisic acid. Plant Science Today 2018;5(2):72-80. https://dx.doi.org/10.14719/pst.2018.5.2.388

\section{Introduction}

Drought is a period with low average precipitation leading to prolonged shortage of water in a given area. According to Mishra and Cherkauer (2010), the shortage in precipitation is coupled with the higher rate of evapotranspiration which results into the agricultural drought (1). The agricultural drought is lack of sufficient moisture content in the soil to meet the normal growth and development of plants (2). There are number of factors that cause reduction in the yield of crops but drought is the most frequent factor related to the reduced production of crops (3). Therefore, efforts should be made to improve the crop yield by $40 \%$ by 2025 in those areas where water is limiting factor (4). In 2018, the world population is 7.6 billion, by 2025 it is expected to increase to 8.5 billion and in 2050 the world population will be 9.7 billion (UNDESA, 2015) (5). The major challenge to the present crop system is to increase the crop production to create sufficient food to feed the increasing population and to reduce the number of starving people by $50 \%$ (6). In plants, the drought affects the basic biochemical and physiological processes like photosynthesis, respiration, nutrient metabolism, ion uptake capacity etc. which are directly associated with the productivity of the plants $(7,8)$. The consequences of drought stress vary at cellular level with respect to plant species, stress duration, stage of plant development etc. (9). It was reported that sometime severe drought can even arrest the photosynthesis and lead to plant death (10). 


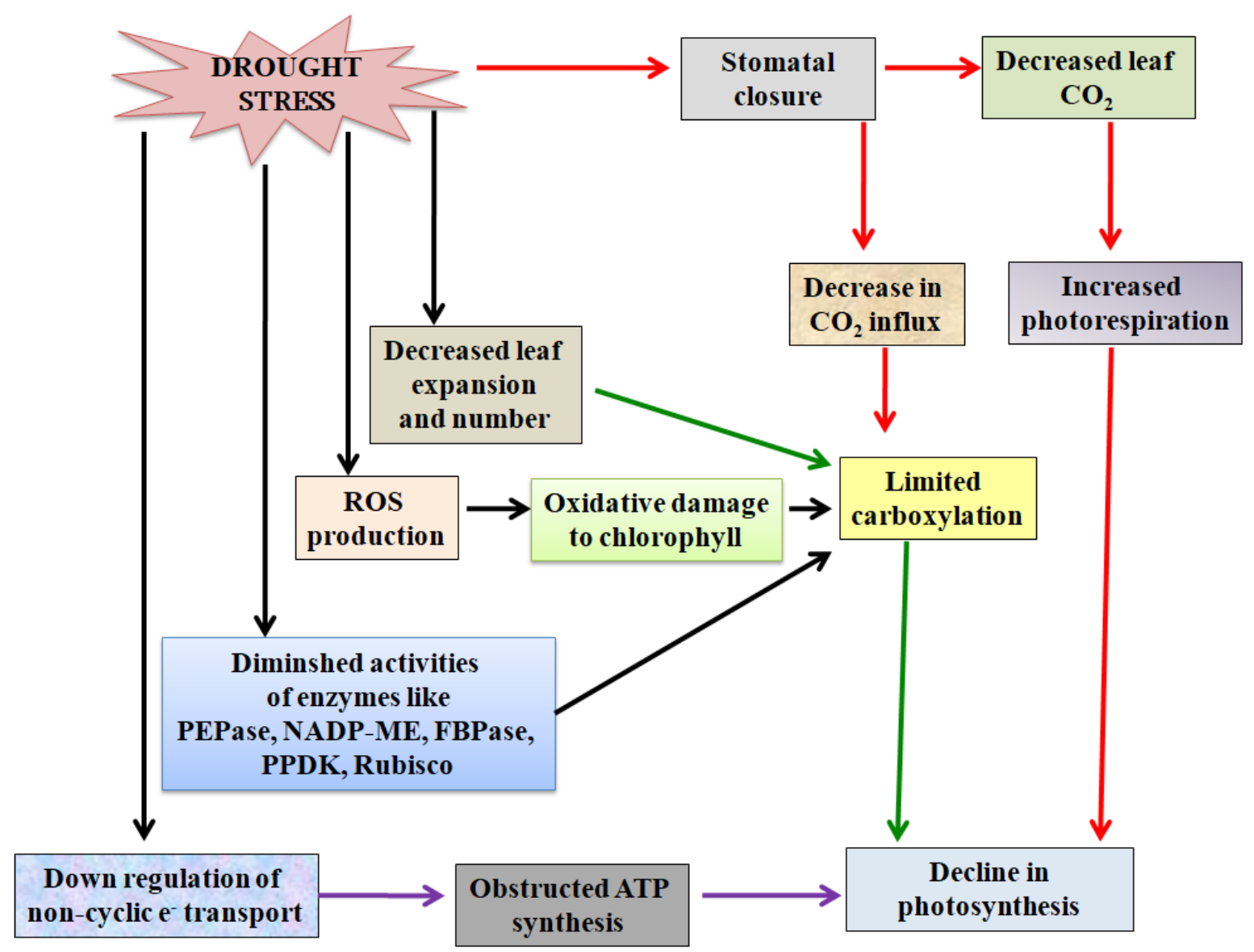

Fig. 1. The consequences of plant to drought stress (15)

Therefore, the development of drought-tolerant plants is the need of the hour to the areas which are at risk of frequent drought.

\section{Areas of world under the risk of severe drought}

Some of the areas of world which are facing severe drought are Cape Town, Malawi, Somalia of South Africa, Italy and Spain in Europe, Southern and Eastern part of India, Bangkok in Thailand etc. (11, 12).

There are number of other areas which are at the risk of severe drought. The plant are the very first recipients of any stress because of their immobility. Therefore, it is very essential to understand the basic phenomenon occurring in plant during such conditions.

\section{Drought stress induced consequences among plants}

The drought during any stage of plant life cycle can result in different morphological, physiological and biochemical consequences in plants and few of them are discussed as follows (Fig. 1):

i. Reduced plant growth and development: The very first and foremost effect of drought is reduced germination and seedling establishment (13). In most of the crops, the germination is reported to reduce under drought stress. The growth of any plant is dependent upon division, elongation, and differentiation of the cells. The drought is reported to reduce turgor pressure of cell which is directly associated with the cell division (14). Drought is also found to affect the crop phenology (i.e. the different growth and developmental aspects of the plant with respect to time) (15). Moreover, drought stress can trigger the early switching of plant developmental stage i.e. a plant can enter early from its vegetative phase to reproductive phase (16).

ii. Disturbance in plant water relationship: The plant water relation includes relative water content (RWC), water potential, osmotic potential, pressure potential, and transpirational rate (TR) (9, 17). These all indices associated with plant water relation are greatly affected by reduced content of water in the soil. It was reported that in the crop plants, the decrease in RWC, TR is coupled with the increase in leaf temperature (18).

iii. Impaired nutrient uptake and assimilation: The nutrients come from the internal cycling of reserve material which is essential for plant growth and biomass accumulation (19). According to Gutierrez-Bemand and Thomas (1999) the absorption of nutrients depends upon absorption kinetics of nutrients, soil nutrient supply, morphology and growth of roots (20). During water deficit, the nutrient supply gets decreased because of slow diffusion of nutrients due to the 


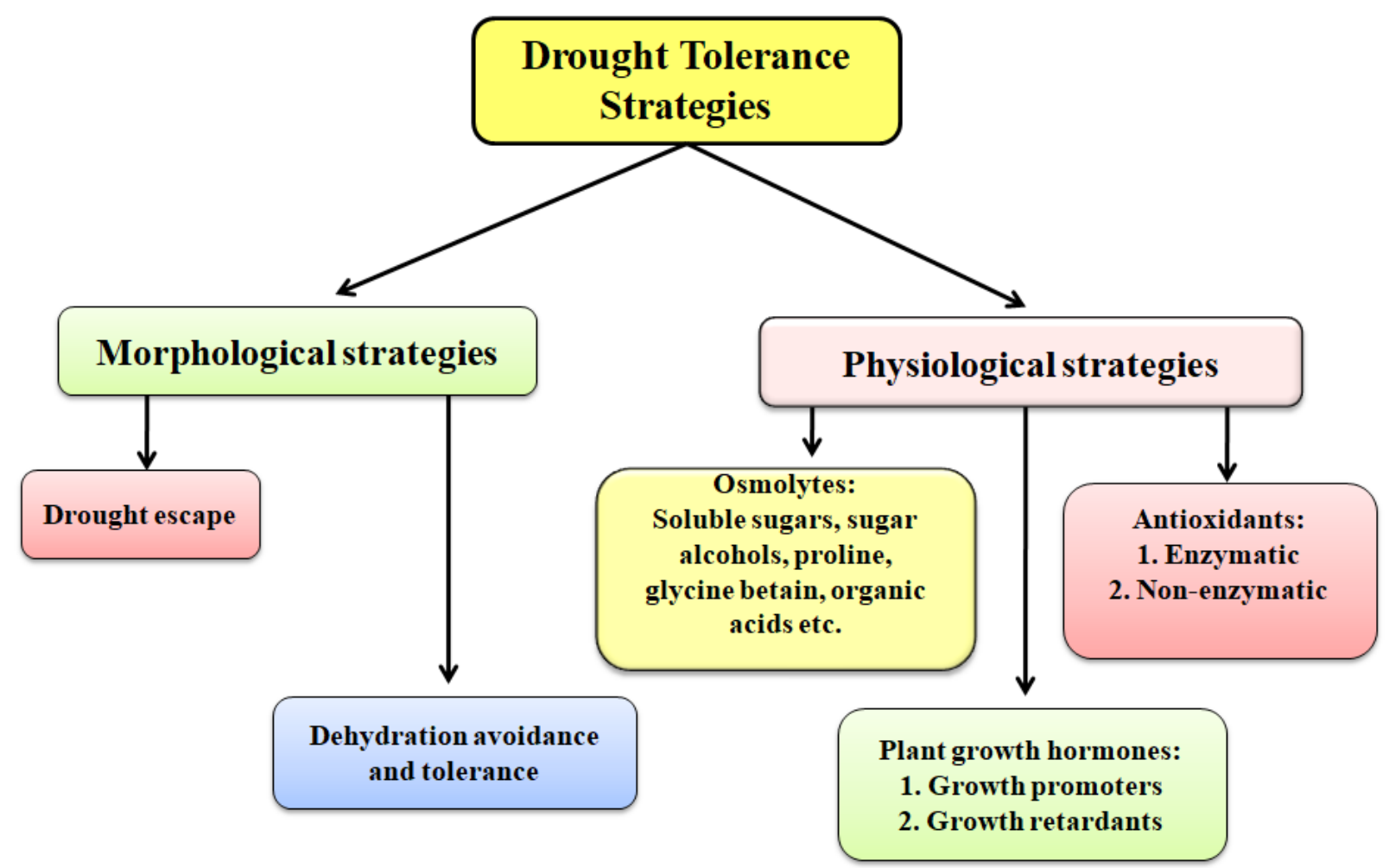

Fig. 2. Morphological and physiological strategies adopted by crop plants during drought stress

decline in soil-water potential (9). The reduced TR is associated with disturbed nutrient uptake to some extent. It may occur because of the limited energy available for the assimilation of $\mathrm{NO}_{3}{ }^{-} / \mathrm{NH}_{4}{ }^{+}$, $\mathrm{PO}_{4}{ }^{3-}$, and $\mathrm{SO}_{4}{ }^{2-}$ and alteration in membrane permeability $(21,22)$.

iv. Oxidative damage: Generally, in plants under abiotic stress the generation of reactive oxygen species (ROS) takes place. The ROS includes superoxide anion, hydroxyl radicals, hydrogen peroxide, alkoxy radicals, and singlet oxygen that are responsible for number of injuries in plant cell (23).

There are number of other consequences also reported during drought stress like disturbed respiration, ATP synthesis, photosynthesis etc.

\section{Drought tolerance strategies adopted by plants}

Due to sessile nature of plants or anchored in one place during abiotic/biotic stress; plant adopt various morphological and physiological strategies for their survival which are as follows (Fig. 2):

1. Morphological strategies: The morphological strategies include drought escape and dehydration avoidance by some morphological modifications.

i. Drought escape: When a plant completes its life cycle/becomes dormant before the onset of the drought then this ability of plant is referred as drought escape. Drought escape is generally observed in some plants growing in desert areas. The life cycle of these plants is extremely short as compared to others and for further propagation of them, they produce seeds during short rainy seasons (24).

ii. Avoidance of dehydration: During scarcity of water if a plant is able to maintain its normal plant water content/cellular hydration or by minimizing water loss through transpiration (25) is referred as dehydration avoidance. For this, plants undergo some morphological modifications to minimize stress-induced consequences. Crops plants were reported to extract more water during drought from the soil so that they can better resist against drought (26). The root plasticity is another important characteristic of a genotype to regulate the growth pattern root accordingly (27). The deeper root system, more root proliferation, root length density are considered drought avoidance traits among plants $(26,28,29)$ and crop genotypes with more root growth are preferred in drought prone areas.

2. Physiological strategies: The plants under drought stress generally adopt physiological adaptations such as osmotic adjustment, roles of plant growth regulators (PGRs) and antioxidative defense system in minimization of damages/injuries.

i. Osmotic adjustment: According to Serraj and Sinclair (2002) the osmotic adjustment is accumulation of such organic/inorganic solute (osmolytes) in cell during stress which are helpful in maintaining lower water potential in cell without declining actual water content thus, drives water from soil (30). The commonly reported 
osmolytes during drought stress are proline, soluble sugars, glycine betaine (GB), organic acids, trehalose etc. (9) and osmolytes are also called as compatible solutes. They maintain the turgor pressure of cell and promote water uptake of roots without causing any harmful effects.

ii. Role of PGRs: The main PGRs are auxins, gibberlins, cytokinins, ethylene and abscisic acid (ABA). From these gibberlins and cytokinins promotes the growth of plant, while ethylene and ABA produce growth retarding effects (33). It was observed that during stress the concentration of growth retarding PGRs get increased and growth promoting PGRs decreased to cope up with the stress.

iii. Role of antioxidative defense system: The stressful conditions enhanced the generation of reactive oxygen species (ROS) in plant and ROS affect the plant's biochemical and physiological processes via oxidative damage to lipids of membrane, proteins, other macromolecules of cell. The antioxidative defense system regulate the ROS induced damage by its enzymatic and nonenzymatic components (34). The enzymatic components include superoxide dismutase (SOD), catalase (CAT), guaiacol peroxidase (GPX), ascorbate peroxidase (APX), glutathione reductase (GR), while non-enzymatic components include ascorbic acids, compatible solutes, $\alpha$-tocopherol, $\beta$ carotene, zeathanxin etc. The protective action of antioxidative enzymes against ROS are explained as follows (35):
a. $\mathrm{O}_{2}{ }^{-}+\mathrm{O}_{2}{ }^{-}+2 \mathrm{H}^{+} \stackrel{\text { SOD }}{\longrightarrow} \mathrm{H}_{2} \mathrm{O}_{2}+\mathrm{O}_{2}$
b. $\mathrm{H}_{2} \mathrm{O}_{2} \stackrel{\mathrm{CAT}}{\longrightarrow} \mathrm{H}_{2} \mathrm{O}+\mathrm{O}_{2}$
c. $4 \mathrm{H}_{2} \mathrm{O}_{2}+$ Guaiacol $\stackrel{\text { GPX }}{\longrightarrow} 8 \mathrm{H}_{2} \mathrm{O}+$ Tetraguaiacol
d. Ascorbate $+\mathrm{H}_{2} \mathrm{O}_{2} \stackrel{\text { APX }}{\longrightarrow}$ Mono-dehydroascorbate $+2 \mathrm{H}_{2} \mathrm{O}$
e. $\mathrm{H}_{2} \mathrm{O}_{2}+$ Glutathione_ $\mathrm{GR} \longrightarrow \mathrm{H}_{2} \mathrm{O}+$ oxidized glutathione

The knowledge of morphological and physiological strategies under drought stress has been extensively explored to develop number of transgenic crops with enhanced drought tolerance in previous.

During drought, the occurrence of the osmotic stress usually takes place which is associated with the abscisic acid (ABA) accumulation in the stressed plant. The increased amount of ABA decreases the stomatal conductance to minimize the water loss via transpiration (36). Therefore, to cope up with such challenges to agricultural system, the understanding of the effects of drought on plants is very crucial and very important. The water deficit may induce or repress the expression of number of genes. A number of techniques are available for knowing the insights of expression of different genes during stress. The microarray technology, RNA sequencing, transcriptome study etc. are few of them. The recently identified dehydration-inducible genes through microarray technology are mainly divided into two groups:

1. There are some common protein and enzymes which play an important role in the tolerance towards abiotic stress. These are chaperones, late embryogenesis abundant proteins, RNA binding proteins, enzymes for osmolyte biosynthesis, osmotin, RNA-binding proteins, water channel proteins, proline transporters etc. (37).

2. The proteins like transcription factors (TFs), protein kinases, protein phosphatase, enzymes of phospholipids metabolism etc. are the main regulatory proteins (37).

Number of strategies were reported to deal with drought stress and among them ABA engineering is one of the most important. ABA is an isoprenoid (Fig. 3) which act as antitranspirant, inhibitor of fruit ripening and act as growth inhibitor of endodermis of roots under salty environment (38).

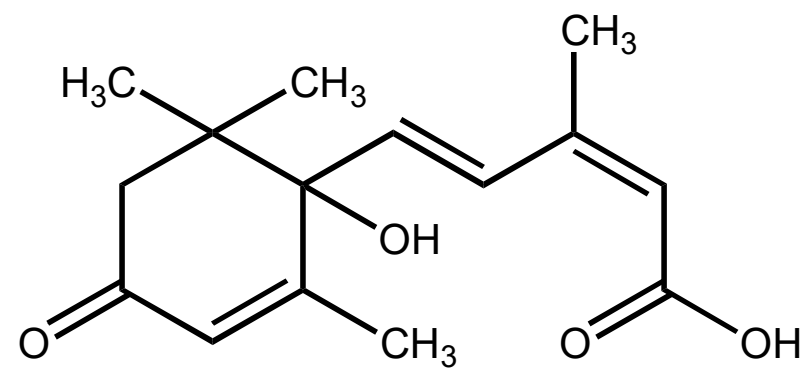

Fig. 3. Structural representation of ABA

ABA biosynthesis take place via $\beta$-carotene through several enzymatic steps (Fig. 4). Under stressful conditions, number of genes are expressed for biosynthesis of ABA like zeaxanthin oxidase (ZEP), 9-cis-epoxycarotenoid dioxygenase (NCED), ABA-aldehyde oxidase (AAO) and molybdenum cofactor sulphurase (MCSU) (39).

The ABA-induced signal transduction is divided into two types: ABA-dependent and ABAindependent pathway.

ABA-dependent gene expression: During stress, there is elevation in the content of $A B A$ and the increased amount of ABA cause binding of itself with receptors for the initiation of signal transduction. There are three main components of ABA dependent signal transduction:

(i) pyrabactin resistance (PYR)/pyrabactin resistance like (PYL)/regulatory components of ABA receptors (RCAR);

(ii) protein phosphatase $2 \mathrm{C}(\mathrm{PP} 2 \mathrm{C})$ and

(iii) sucrose non-fermenting (SNF1) related protein kinase 2 (SnPK2).

In signal transduction of ABA, PP2C act as negative regulator, while SnPK2 acts as positive regulator $(40,41)$. $\mathrm{ABA}$ is known to acts as an 


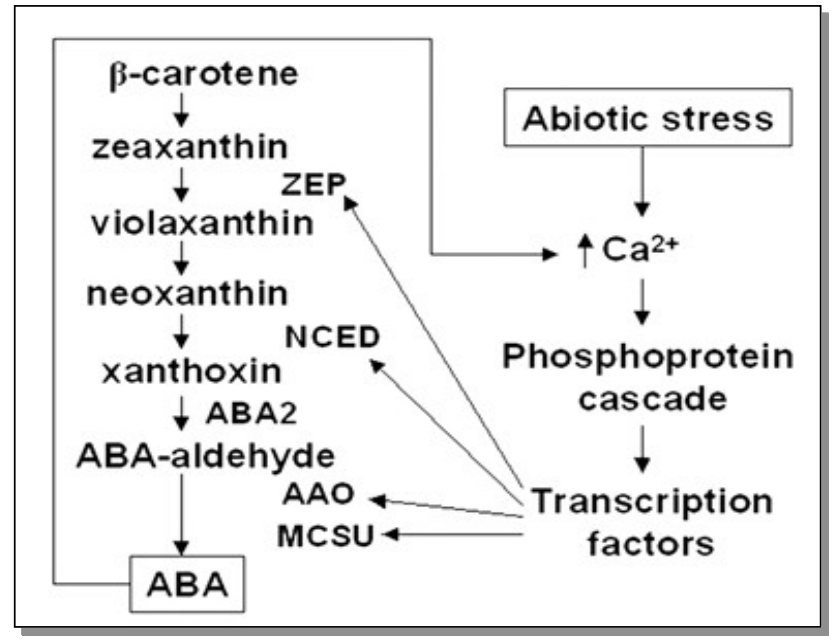

Fig. 4. ABA biosynthesis (39)
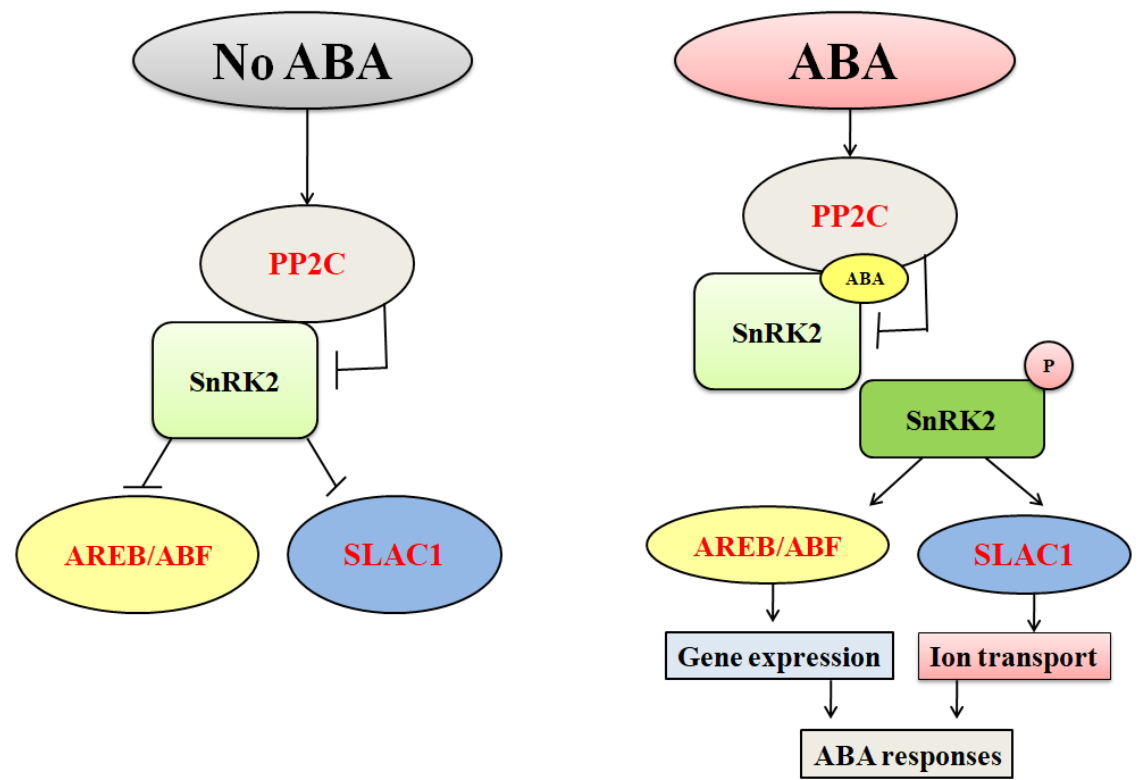

Fig. 5. ABA dependent signaling (52)

endogenous messenger in plants under stressed condition and the promoter regions of many ABAresponsive genes contain a conserved cis-element that is ABA-responsive element (ABRE), PyACGTGG/TC which plays major role in ABAdependent gene expression (37). ABRE also requires another cis-acting element which is $\mathrm{CE}$ (coupling element) to achieve ABA induction (42). In the absence of ABA or normal conditions, PP2C is bound to SnRK2 which actually ceases the phosphorylation of downstream substrates and no signal transduction takes place. In the presence of $\mathrm{ABA}$, it bound to ABA receptors (RCARs/PYR1/PYL) to form a complex. The formation of this complex provides an active site for the PP2C (negative regulator) and in the presence of ABA, PP2C facilitate the phosphatase activity of SnRK2 which is the first step of ABA-responsive regulation pathway. Thus, multiple step phosphorylation of
SnRK2 activates the ABRB (ABRE-binding protein)/ $\mathrm{ABF}$ (ABRE-binding factor) which finally induce gene expression (Fig. 5) (43). ARBE and ABF are basic leucine zipper (bZIP) transcription factors (37). Moreover, the activation of these ABA receptors allows SnRK2s to phosphorylate some other target proteins, like S-type slow anion channel (SLAC1) responsible for controlling stomatal response under normal/stressed conditions (44). It is a 10-transmembrane domain protein possesses an extended cytosolic N-terminal region which contains an OST1 phosphorylation site essential for its activity $(45,46)$. Expression of SLAC1 and OST1 is required for channel activity. SLAC1, itself seldom causes channel activity (29). In ABA-dependent signaling, it was reported that the accumulation of $\mathrm{K}^{+}$in guard cell is also SnRK2dependent. Thus, these receptors, PYR/PYL/RCAR, PP2Cs and SnRK2 play central role in controlling 
ABA dependent signaling. Moreover, for terrestrial plants $\mathrm{AREB} / \mathrm{ABF}$ is considered more useful and the phosphorylation of AREB/ABF by SnRK2 is also considered as a critical step for enhancing drought tolerance among crops (47, 48, 49, 50). Recently, the evolution of PP2C was reported earlier among terrestrial plants as key regulators of intrinsic desiccation tolerance. The signaling factors such as PYL (e.g. PYL4) can also be used for improving stress tolerance among terrestrial plants $(51,52)$.

ABA-independent pathway: In ABA-dependent pathway ABRE plays main role, while in ABAindependent pathway dehydration responsive element/C-Repea T (DRE/CRT) plays important role and the promoter of this also contains conserved cis-acting motif i.e. A/GCCGAC (37). The two transcriptional factors CBF/DREB1, CBF/DREB2 (Crepeat binding factor/dehydration-responsive element binding protein) belonging to AP2/ERF family bind to DRE/CRT element (53). It was reported that the interaction of DREB1 with DRE/CRT controls the expression of various stress responsive genes in Arabidopsis (54). The drought, salinity and freezing stress-tolerance were recorded to improve during the overexpressing DREB1/CBF TFs in the transgenic Arabidopsis but their constitutive expression cause growth defects. Thus, the overexpression of DREB/CBF TFs has been well reported to improve and enhance the drought tolerance in transgenic crops. Therefore, TFs can be used to improve drought tolerance in a variety of crop plants.

\section{Post transcriptional regulation of $\mathrm{ABA}$}

The gene expression of ABA can also be controlled after the transcription mainly via alternative splicing and RNA silencing $(55,56)$. The final product of transcription is pre-mRNA which is capped and polyadenylated. During maturation of mRNA, pre-mRNA undergo splicing which is the removal of introns from pre-mRNA. Similarly, alternative splicing (AS) is also removal of introns but it gives rise to more than one mRNA from a single gene. It is mainly of five types: exon skipping, alternative $5^{\prime}$ splice site, alternative $3{ }^{\prime}$ splice site and intron retention (Fig. 6). According to Reddy et al. (2007) in Arabidopsis thaliana 30\% transcripts are spliced through AS (57). The splicing is mediated through spliceosome and SERINE/ARGININE RICH (SR) protein is an integral part of that which plays a key role in the regulation of splicing in eukaryotes (58). SR belong to a highly conserved family of RNA-binding proteins and it execute and regulate pre-mRNA splicing in different part of plant in response to stress (59). Alternative splicing results in the availability of different transcripts which ultimately results in the formation of different proteins which might be helpful in drought stress tolerance (55). Moreover, alternative splicing can also auto-regulate the various TFs under stress Guerra et al. (2015) (60). For example, alternative splicing of a transcript encoding DROGHT RESPONSIVE ANKYRIN 1 (DRA1) protein via intron retention mechanism is reported to involve in the drought tolerance in Arabidopsis thaliana (60).

The RNA silencing is a process of down regulation of some transcripts via the action of different small RNAs (56) and in these small-RNAs, the regulations of drought stress were mostly reported via micro RNAs (miRNA). These are endogenous small non-coding RNAs which act on target genes of mRNA by sequence pairing thus, inhibiting their translation or cleaving them (61). The various studies reported the role of miRNAs in the development of drought tolerant crops and further should explored.

There are number of transgenic crops have been produced in last decades and some them are Indian mustard, maize, wheat, and rice etc. These were made drought resistant via over accumulation of GB, protection of photosynthetic

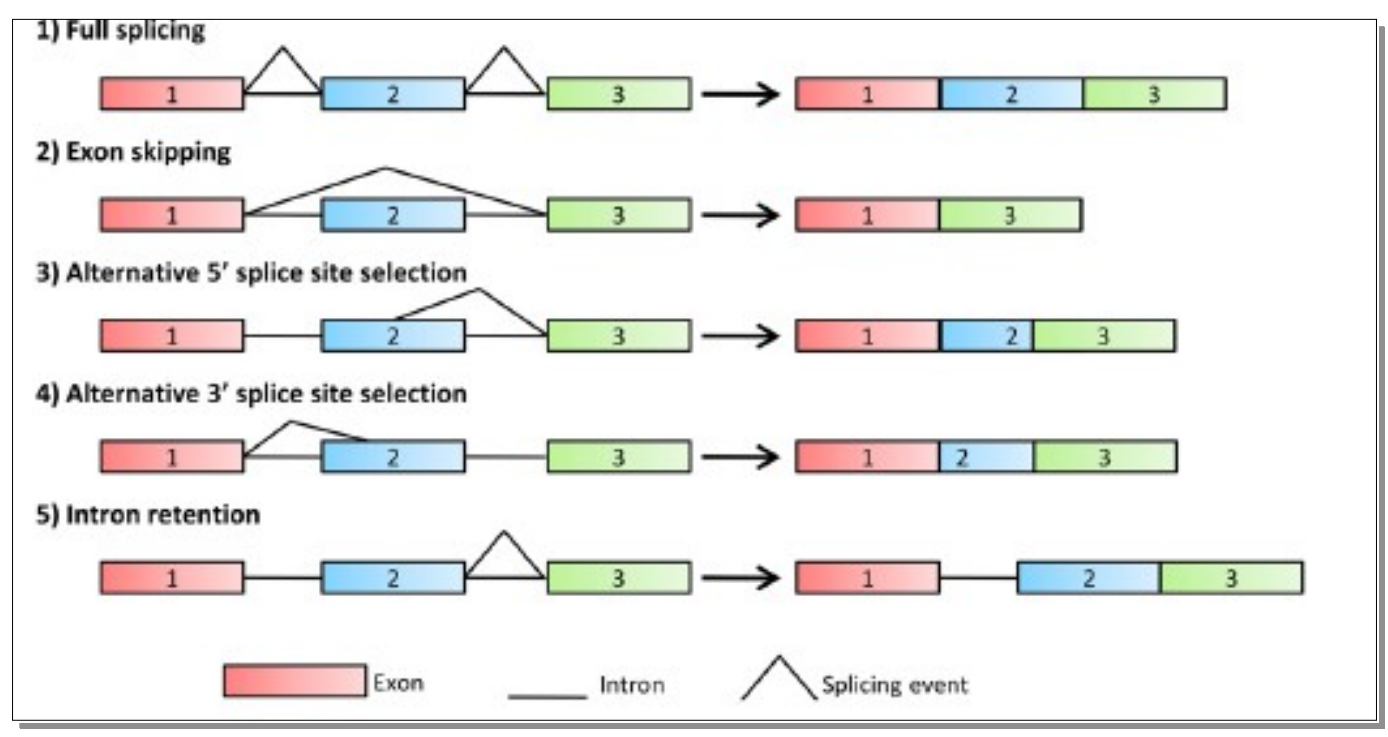

Fig. 6. Types of alternative splicing (60) 
machinery from damage caused by dehydration and accumulation of trehalose respectively $(62,63$, $64)$.

\section{Conclusions}

The great leaps and bounds in the field of plant drought stress responses and tolerance mechanisms have been achieved in the last decades but many challenges still lie there. Thus, the recent techniques and methods of molecular breeding and advanced biotechnology might be helpful for the development of crops with increased drought tolerance. In this context, relevant genes involve in signal transduction may be useful in enhancing drought tolerance and can further be explored more using different recent technologies. Thus, it can positively influence the capability of the crop plants to deal with the frequent drought stress in such areas which are more prone to drought.

\section{Conflict of Interest}

There is no conflict of interest among the authors.

\section{Acknowledgements}

Authors are highly thankful to University Grants Commission for providing financial assistance under UPE (University with Potential for Excellence) scheme and Guru Nanak Dev University, Amritsar for providing necessary infrastructure to carry out the research work.

\section{Authors contributions}

All the authors contributed equally to prepare the review article.

\section{References}

1. Mishra V, Cherkauer KA. Retrospective droughts in the crop growing season: Implications to corn and soybean yield in the Midwestern United States. Agricultural and Forest Meteorology 2010; 150(7-8): 1030-45. doi: 10.1016/j.agrformet.2010.04.002

2. Manivannan P, Jaleel CA, Somasundaram R, Panneerselvam R. Osmoregulation and antioxidant metabolism in drought-stressed Helianthus annuus under triadimefon drenching. Comptes Rendus Biologies 2008; 331(6): 418-25. doi: 10.1016/j.crvi.2008.03.003

3. Boyer JS. Plant productivity and environment. Science 1982; 218(4571): 443-48. doi: 10.1126/science. 218.4571 .443

4. Pennisi E. The blue revolution, drop by drop, gene by gene. Science 2008; 320(5873): 171-73. doi: 10.1126/science.320.5873.171

5. World population projected to reach 9.7 billion by 2050 [Internet].; [cited 6 March 2018]. Available from: http://www.un.org/en/development/desa/ news/population/2015-report.html

6. FAO (Food and Agriculture Organisation), Rome [Internet].; [cited 6 March 2018]. Available from: http://www. fao.org/spfs/about-spfs/mission-spfs/en/

7. Mahajan S, Tuteja N. Cold, salinity andijllh drought stresses: an overview. Archives of Biochemistry and Biophysics 2005;444(2): 139-58. doi: 10.1016/j.abb.2005.10.018

8. Shao HB, Chu LY, Jaleel CA, Manivannan P, Panneerselvam R, Shao MA. Understanding water deficit stress-induced changes in the basic metabolism of higher plants-biotechnologically and sustainably improving agriculture and the ecoenvironment in arid regions of the globe. Critical Reviews in Biotechnology 2009; 29(2): 131-51. doi: $10.1080 / 07388550902869792$

9. Farooq $\mathrm{M}$, Wahid $\mathrm{A}$, Lee DJ, Ito $\mathrm{O}$, Siddique $\mathrm{KH}$. Advances in drought resistance of rice. Critical Reviews in Plant Sciences 2009; 28(4): 199-17. doi: $10.1080 / 07352680902952173$

10. Lawlor DW, Cornic G. Photosynthetic carbon assimilation and associated metabolism in relation to water deficits in higher plants. Plant, Cell \& Environment 2002; 25(2): 275-294. doi: 10.1046/j.0016-8025.2001.00814.X

11. Kaya MD, Okçu G, Atak M, Cıkılı Y, Kolsarıcı Ö. Seed treatments to overcome salt and drought stress during germination in sunflower (Helianthus annuus L.). European Journal of Agronomy 2006; 24(4): 291-95. doi: 10.1016/j.eja.2005.08.001

12. Drought [Internet].; [cited 1 June 2017]. Available from: https://wachers.news/category/drought/

13. Drought - Environment - The Guardian [Internet].; [cited 6 March 2018]. Available from: https://www.theguardian.com/environment/drought

14. Taiz L, Zeiger E. Plant Physiology, 4th Ed. Sinauer Associates Inc. Publishers, Massachusetts; 2006.

15. Farooq M, Hussain M, Wahid A, Siddique KHM. Drought stress in plants: an overview. In Plant Responses to Drought Stress. Springer, Berlin, Heidelberg 1-33; 2012. doi: 10.1007/978-3-642-326530_1

16. Desclaux D, Roumet P. Impact of drought stress on the phenology of two soybean (Glycine max L. Merr) cultivars. Field Crops Research 1996; 46(1-3): 61-70. doi: 10.1016/0378-4290(95)00086-0

17. Kirkham MB. 8-Field Capacity, Wilting Point, Available Water, and Nonlimiting Water Range. Principles of Soil and Plant Water Relations, Elsevier Academic Press 101-15; 2005.

18. Siddique MRB, Hamid A, Islam MS. Drought stress effects on water relations of wheat. Botanical Bulletin of Academia Sinica 2000; 41: 35-39.

19. Singh B, Singh G. Influence of soil water regime on nutrient mobility and uptake by Dalbergia sissoo seedlings. Tropical Ecology 2004; 45(2): 337-340.

20. Gutiérrez-Boem FH, Thomas GW. Phosphorus nutrition and water deficits in field-grown soybeans. Plant and Soil 1999; 207(1): 87-96. doi: 10.1023/A:1004469403667 
21. Grossman A, Takahashi H. Macronutrient utilization by photosynthetic eukaryotes and the fabric of interactions. Annual Review of Plant Biology 2001; 52(1): 163-10.

22. Baligar VC, Fageria NK, He ZL. Nutrient use efficiency in plants. Communications in Soil Science and Plant Analysis 2001; 32(7-8): 921-50. doi: 10.1081/CSS-100104098

23. Munne-Bosch S, Penuelas J. Photo-and antioxidative protection, and a role for salicylic acid during drought and recovery in field-grown Phillyrea angustifolia plants. Planta 2003; 217(5): 758-66. doi: 10.1007/s00425-003-1037-0

24. Levitt J. Responses of plants to environmental stresses. In: Kozlowski TT (ed) Water, radiation, salt and other stresses. Academic, New York, $2^{\text {nd }}$ edn., 93-186; 1980.

25. Blum A. Drought resistance, water-use efficiency, and yield potential-are they compatible, dissonant, or mutually exclusive? Australian Journal Agricultural Research 2005; 56: 1159-68.

26. Gowda VRP, Henry A, Yamauchi A, Shashidhar HE, Serraj R. Root biology and genetic improvement for drought avoidance in rice. Field Crops Research 2011; 122: 1-13. doi: 10.1016/j.fcr.2011.03.001

27. Yamauchi Y, Pardales JR, Kono Y. Root system structure and its relation to stress tolerance. In: Roots and nitrogen in cropping systems of the semiarid tropics 211-33; 1996.

28. Wang H, Yamauchi A. Growth and functions of roots under abiotic stress in soil. In: Huang B (ed) Plantenvironment interactions. 3rd edn. CRC Press, New York, 271-320; 2006.

29. Kavar T, Maras M, Kidric M, Sustar-Vozlic J, Meglic $\mathrm{V}$. Identification of genes involved in the response of leaves of Phaseolus vulgaris to drought stress. Molecular Breeding 2007; 2: 159-72.

30. Serraj R, Sinclair TR Osmolyte accumulation: can it really help increase crop yield under drought conditions? Plant, Cell Environment 2002; 25: 33341. doi: 10.1046/j.1365-3040.2002.00754.X

31. Chimenti CA, Marcantonio M, Hall AJ. Divergent selection for osmotic adjustment results in improved drought tolerance in maize (Zea mays L.) in both early growth and flowering phases. Field Crops Research 2006; 95: 305-15. doi: 10.1016/j.fcr.2005.04.003

32. Kiani SP, Talia P, Maury P, Grieu P, Heinz R, Perrault A, Nishinakamasu V, Hopp E, Gentzbittel L, Paniego N, Sarrafi A. Genetic analysis of plant water status and osmotic adjustment in recombinant inbred lines of sunflower under two water treatments. Plant Science 2007; 172: 773-87. doi: 10.1016/j.plantsci.2006.12.007

33. Taiz L, Zeiger E. Plant Physiology. 5th edn. Sinauer Associates Inc. Publishers, Massachusetts; 2010.

34. Ahmad P, Alyemeni MN, Ahanger MA, Wijaya L, Alam P, Kumar A, Ashraf M. Upregulation of antioxidant and glyoxalase systems mitigates $\mathrm{NaCl}$ stress in Brassica juncea by supplementation of zinc and calcium. Journal of Plant Interactions 2018; 13(1): 151-62. doi: 10.1080/17429145.2018.1441452
35. Kaur, R. Growth biochemical and antimutagenic studies on Chlorophytum borivilianum Sant et Fernand. Ph.D. Thesis, Guru Nanak Dev University, Amritsar; 2013.

36. Yamaguchi-Shinozaki K, Shinozaki K. Transcriptional regulatory networks in cellular responses and tolerance to dehydration and cold stresses. Annual Review of Plant Biology 2006;57:78103. doi: 10.1146/annurev.arplant.57.032905.105444

37. Buchanan BB, Gruissem W, Jones, RL. Biochemistry \& Molecular Biology of Plants. Rockville, MD: American Society of Plant Physiologists; 2015.

38. Abscisic acid - Wikipedia [Internet].; [cited 6 March 2018]. Available from: https://en.wikipedia.org/wiki/ Abscisic_acid

39. Tuteja N. Abscisic acid and abiotic stress signaling. Plant Signaling \& Behavior 2007; 2(3): 135-38. doi: 10.4161/psb.2.3.4156

40. Finkelstein RR, Rock CD. Abscisic Acid Biosynthesis and Response. In: The Arabidopsis Book. American Society of Plants 1-52; 2002. doi: 10.1199/tab.0058

41. Zandkarimi H, Ebadi A, Salami SA, Alizade H. Analyzing the expression profile of AREB / ABF and DREB / CBF genes under drought and salinity stresses in grape (Vitis vinifera L.). PloS One 2015; 116. doi: 10.1371/journal.pone.0134288

42. Hobo T, Asada M, Kowyama Y. ACGT-containing abscisic acid response element (ABRE) and coupling element 3 (CE3) are functionally equivalent. The Plant Journal 1999; 19(6): 679-89. doi: 10.1046/j.1365313x.1999.00565.x

43. Yoshida T, Mogami J, Yamaguchi-Shinozaki K. ABAdependent and ABA-independent signaling in response to osmotic stress in plants. Current Opinion in Plant Biology 2014; 21: 133-39. doi: 10.1016/j.pbi.2014.07.009

44. Hubbard KE, Nishimura N, Hitomi K, Getzoff ED, Schroeder JI. Early abscisic acid signal transduction mechanisms: newly discovered components and newly emerging questions. Genes \& Development 2010; 24(16): 1695-08. doi: 10.1101/gad.1953910

45. Lee SC, Lan W, Buchanan BB, Luan S. A protein kinase-phosphatase pair interacts with an ion channel to regulate ABA signaling in plant guard cells. Proceedings of the National Academy of Sciences 2009; 106(50): 21419-24. doi: 10.1073/pnas.0910601106

46. Vahisalu T, Puzorjova I, Brosche M, Valk E, Lepiku $\mathrm{M}$, Moldau $\mathrm{H}$, Pechter $\mathrm{P}$, Wang YS, Lindgren, $\mathrm{O}$, Salojarvi J. et al. Ozone-triggered rapid stomatal response involves the production of reactive oxygen species, and is controlled by SLAC1 and OST1. The Plant Journal 2010; 62: 442-53. doi: 10.1111/j.1365313X.2010.04159.X

47. Nakashima K, Yamaguchi-Shinozaki K, Shinozaki K. The transcriptional regulatory network in the drought response and its crosstalk in abiotic stress responses including drought, cold, and heat Frontiers in Plant Science 2014; 57(10): 170. doi: 10.3389/fpls.2014.00170

48. Miyakawa T, Fujita Y, Yamaguchi-Shinozaki K, Tanokura M. Structure and function of abscisic acid 
receptors. Trends in Plant Science, 2013; 18(5): 25966. doi: 10.1016/j.tplants.2012.11.002

49. Nakashima K, Yamaguchi-Shinozaki K. ABA signaling in stress-response and seed development. Plant Cell Reports 2013; 32(7): 959-70. doi: 10.1007/s00299-013-1418-1

50. Fujita Y, Nakashima K, Yoshida T, Katagiri T, Kidokoro S, Kanamori N, Kobayashi M. Three SnRK2 protein kinases are the main positive regulators of abscisic acid signaling in response to water stress in Arabidopsis. Plant and Cell Physiology 2009; 50(12): 2123-32. doi: 10.1093/pcp/pcp147

51. Komatsu K, Suzuki N, Kuwamura M, Nishikawa Y, Nakatani M, Ohtawa H, et al. Group A PP2Cs evolved in land plants as key regulators of intrinsic desiccation tolerance. Nature Communications 2013; 4: 2219. doi: 10.1038/ncomms3219

52. Pizzio GA, Rodriguez L, Antoni R, Gonzalez-Guzman M, Yunta C, Merilo E, et al. The PYL4 A194T mutant uncovers a key role of PYR1- LIKE4/PROTEIN PHOSPHATASE 2CA interaction for abscisic acid signaling and plant drought resistance. Plant Physiology 2013; 163: 441-55.

53. Liu Q, Kasuga M, Sakuma Y, Abe H, Miura S, Yamaguchi-Shinozaki K, Shinozaki K. Two transcription factors, DREB1 and DREB2, with an EREBP/AP2 DNA binding domain separate two cellular signal transduction pathways in droughtand low-temperature-responsive gene expression, respectively, in Arabidopsis. The Plant Cell 1998; 10(8): 1391-06. doi: 10.1105/tpc.10.8.1391

54. Sakuma Y, Maruyama K, Osakabe Y, Qin F, Seki M, Shinozaki K, Yamaguchi-Shinozaki K. Functional analysis of an Arabidopsis transcription factor, DREB2A, involved in drought-responsive gene expression. The Plant Cell 2006; 18(5): 1292-09.

55. Mastrangelo AM, Marone D, Laidò G, De Leonardis AM, De Vita P. Plant Science 2012; 185-186: 40-49. doi: 10.1016/j.plantsci.2011.09.006

56. Kruszka K, Pieczynski M, Windels D, Bielewicz D, Jarmolowski A, Szweykowska-Kulinska Z. et al. Role of microRNAs and others RNAs of plants in their changing environments. Journal of Plant Physiology 2012; 169: 1664-72. doi: 10.1016/j.jplph.2012.03.009

57. Reddy, ASN. Alternative splicing of pre-messenger RNAs in plants in the genomic era. Annual Review of Plant Biology 2007; 58: 267-94.

58. Palusa SG, Ali GS, Reddy ASN. Alternative splicing of pre-mRNAs of Arabidopsis serine/arginine-rich proteins: regulation by hormones and stresses. The Plant Journal 2007; 49: 1091-07. doi: 10.1111/j.1365313X.2006.03020.x

59. Duque P. A role for SR proteins in plant stress responses. Plant Signaling \& Behavior 2011; 6: 49-54. doi: $10.4161 / p s b .6 .1 .14063$

60. Guerra D, Crosatti C, Khoshro HH, Mastrangelo AM, Mica E, Mazzucotelli E. Post-transcriptional and post-translational regulations of drought and heat response in plants: a spider's web of mechanisms. Frontier in Plant Science, 2015; 6:57. doi: 10.3389/fpls.2015.00057

61. Axtell MJ. Classification and comparison of small RNAs from plants. Annual Review of Plant Biology 2013; 64: 137-59.

62. Huang J, Hirji R, Adam L, Rozwadowski KL, Hammerlindl JK, Keller WA, Selvaraj G. Genetic engineering of glycine betaine production toward enhancing stress tolerance in plants: metabolic limitations. Plant Physiology 2000; 122: 747-756. doi: 10.1104/pp.122.3.747

63. Shou H, Bordallo P, Wang K. Expression of the Nicotiana protein kinase (NPK1) enhanced drought tolerance in transgenic maize. Journal of Experimental Botany 2004; 55:1013-19. doi: 10.1093/jxb/erh129

64. He C, Zhang CW, Gao Q, Yang A, Hu X, Zhang J. Enhancement of drought resistance and biomass by increasing the amount of glycine betaine in wheat seedlings. Euphytica 2011; 177: 16-151. doi: 10.1007/s10681-010-0263-3 